\title{
Extracorporeal membrane oxygenation for recovery, then elective surgical repair
}

\author{
Vincent R. Conti, MD
}

\author{
From the Division of Cardiothoracic Surgery, Department of Surgery, University of Texas Medical Branch, Gal- \\ veston, Tex. \\ Disclosures: Author has nothing to disclose with regard to commercial support. \\ Received for publication Nov 28, 2017; accepted for publication Dec 4, 2017; available ahead of print Jan 5, 2018 \\ Address for reprints: Vincent R. Conti, MD, Division of Cardiothoracic Surgery, Department of Surgery, Univer- \\ sity of Texas Medical Branch, 301 University Blvd, Galveston, TX 77555-0528 (E-mail: vconti@utmb.edu). \\ J Thorac Cardiovasc Surg 2018;155:e125-6 \\ $0022-5223 / \$ 36.00$ \\ Copyright (C) 2017 by The American Association for Thoracic Surgery \\ https://doi.org/10.1016/j.jtcvs.2017.12.015
}

The sine qua non of the therapeutic approach to ischemic ventricular septal defects is surgical. The 2013 American College of Cardiology Foundation and American Heart Association joint guideline for management of ST-elevation myocardial infarction endorses that "emergency surgical repair is necessary even in hemodynamically stable patients because the rupture can extend abruptly resulting in sudden collapse in previously stable patients." 1 Furthermore, it states that "the surgical mortality rate remains high especially among patients with shock ranging from $20 \%$ to $87 \%$ in reported series." ${ }^{1}$ Fortunately, there is evidence that the implementation of primary percutaneous coronary intervention for acute ST-elevation myocardial infarction has markedly decreased the risk of postinfarction ventricular septal defect (PI-VSD), from $1 \%$ to $3 \%$ before percutaneous coronary intervention for ST-elevation myocardial infarction to $0.23 \%$ today. $^{2}$

Although the incidence of PI-VSD has decreased, it remains associated with significant morbidity and mortality. In their large review of the cases recorded in the Society of Thoracic Surgeons national database, Arnaoutakis and colleagues $^{3}$ reported 2876 patients with PI-VSD, 35\% of whom were operated on urgently and $49.7 \%$ of whom were operated on as an emergency, with an operative mortality of $54.1 \%$ if the operation was done within 7 days of presentation. There has been an improvement in outcomes noted in more recent studies, with Okamoto and associates ${ }^{4}$ reporting on 21 patients, all of whom were in cardiogenic shock, who had a $23.8 \%$ mortality when a triple patch technique was used. Given these still relatively poor surgical outcomes, especially in the presence of deteriorating hemodynamics, as well as the desire to permit infarcted tissue to demarcate and partially heal before surgical repair, Hobbs and coworkers ${ }^{5}$ implemented temporary extracorporeal membrane oxygenation (ECMO) support before attempted surgical repair. Two patients supported only with ECMO for 4 to 7 days then underwent repair, and both survived. The case report in this issue of the Journal by Muller Moran

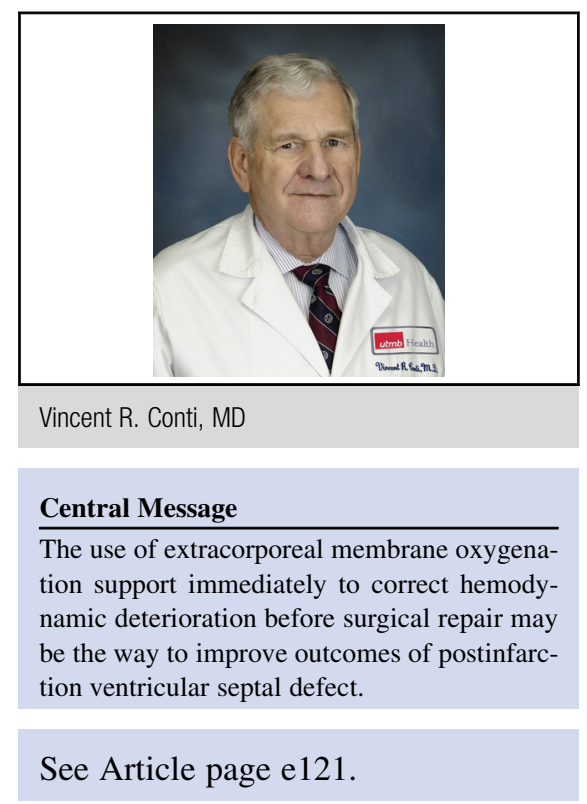

and colleagues ${ }^{6}$ describes a patient with PI-VSD who had deterioration with severe cardiogenic shock and recovered remarkably well with ECMO support for 9 days before operative repair. This patient did require another 6 days of ECMO support before decannulation was done, but he then did well and finally recovered, albeit after a long hospitalization.

Although percutaneous closure of PI-VSD with the Amplatzer occluder device (Abbott Laboratories, Abbott Park, Ill) has been performed successfully, the overall mortality has not significantly improved. The significant variability in the size, shape, and location of the PI-VSD has made the applicability of this intervention less than ideally predictable. $^{7}$

Given the relatively poor results in the past and the technical difficulties with repair early after acute myocardial infarction, these recent results with ECMO support to permit hemodynamic and metabolic recovery suggest that this indeed may be the better approach in these difficult cases. More experience is needed, but perhaps the first signs of hemodynamic deterioration, which usually are what first lead to the diagnosis of PI-VSD, should immediately be treated with ECMO support, with elective repair performed after recovery.

\section{References}

1. O'Gara PT, Kushner FG, Ascheim DD, Casey DE Jr, Chung MK, de Lemos JA, et al; American College of Cardiology Foundation/American Heart Association 
Task Force on Practice Guidelines. 2013 ACCF/AHA guideline for the management of ST-elevation myocardial infarction: a report of the American College of Cardiology Foundation/American Heart Association Task Force on Practice Guidelines. Circulation. 2013;127:e362-425. Erratum in: Circulation. 2013;128: e481.

2. Yip HK, Fang CY, Tsai KT, Chang HW, Yeh KH, Fu M, et al. The potential impact of primary percutaneous coronary intervention on ventricular septal rupture complicating acute myocardial infarction. Chest. 2004; $125: 1622-8$.

3. Arnaoutakis GJ, Zhao Y, George TJ, Sciortino CM, McCarthy PM, Conte JV. Surgical repair of ventricular septal defect after myocardial infarction: outcomes from the Society of Thoracic Surgeons National Database. Ann Thorac Surg. 2012;94: 436-43; discussion 443-4.
4. Okamoto Y, Yamamoto K, Asami F, Kimura M, Mizumoto M, Okubo Y, et al. Early and midterm outcomes of triple patch technique for postinfarction ventricular septal defects. J Thorac Cardiovasc Surg. 2016;151:1711-6.

5. Hobbs R, Korutla V, Suzuki Y, Acker M, Vallabhajosyula P. Mechanical circulatory support as a bridge to definitive surgical repair after post-myocardial infarct ventricular septal defect. J Card Surg. 2015;30:535-40.

6. Muller Moran HR, Dutta V, Yan W, Ghorpade NN, Arora RC, Singal RK, et al. Extracorporeal membrane oxygenation prior to surgical repair of a post-infarction ventricular septal defect. J Thorac Cardiovasc Surg. 2018;155: e121-3.

7. Hamilton MC, Rodrigues JC, Martin RP, Manghat NE, Turner MS. The in vivo morphology of post-infarct ventricular septal defect and the implications for closure. JACC Cardiovasc Interv. 2017;10:1233-43. 